\title{
Romantic attachment, social support, sexual approach style and sociocultural influences on eating disorder symptoms
}

\author{
Cassandra Dean ${ }^{1 *}$, Janice Sabura Allen ${ }^{1}$, Elizabeth Hughes ${ }^{2}$ \\ From 2013 ANZAED Conference: Inspiring Change: Person and Context \\ Melbourne, Australia. 23-24 August 2013
}

The purpose of this study was to examine the prediction of eating disorder symptoms within an integrated theoretically-driven model of romantic attachment, social support, sexual approach styles and the internalization of the media's portrayal of ideal body standards. A community sample of 671 women aged 19 to 88 years completed a series of self-report questionnaires. The findings supported a mediation model of romantic attachment being associated with eating disorder symptoms through interpersonal factors (perceived social support, game-playing and possessive sexual approach styles), and an environmental factor (the internalization of the media's depiction of ideal body standards). Romantic attachment anxiety predicted eating disorder symptoms directly; however, romantic attachment avoidance did not. Instead it predicted other factors. The findings enhance the understanding of the pathways influencing eating disorder symptoms and indicate that the attachment theory is a valuable framework to integrate the literature regarding sociocultural theory, sexual approach style, social support and eating disorders.

This abstract was presented in the Disordered Eating Characteristics \& Treatment stream of the 2013 ANZAED Conference.

\footnotetext{
Authors' details

${ }^{1}$ School of Psychiatry and Psychology, Monash University, Australia. ${ }^{2}$ Centre

for Adolescent Health, The Royal Children's Hospital, Australia.
}

Published: 14 November 2013
doi:10.1186/2050-2974-1-S1-027

Cite this article as: Dean et al: Romantic attachment, social support, sexual approach style and sociocultural influences on eating disorder symptoms. Journal of Eating Disorders 2013 1(Suppl 1):O27.

* Correspondence: Cassandra.Dean@monash.edu

'School of Psychiatry and Psychology, Monash University, Australia

Full list of author information is available at the end of the article

Submit your next manuscript to BioMed Central and take full advantage of:

- Convenient online submission

- Thorough peer review

- No space constraints or color figure charges

- Immediate publication on acceptance

- Inclusion in PubMed, CAS, Scopus and Google Scholar

- Research which is freely available for redistribution
C Biomed Central 